\title{
Interferências linguísticas na interlíngua em alunos hispanofalantes de português como língua estrangeira
}

\section{Linguistic interferences in the interlanguage of native Spanish- speaking learners of Portuguese as a foreign language}

Nildicéia Aparecida Rocha

UNESP

nildirocha@fclar.unesp.br

Ana María del Pilar Altamirano Robles

UNESP

amp.altamirano@gmail.com

Resumo: O presente trabalho estuda como acontecem as interferências linguísticas na interlíngua na aprendizagem de português como língua estrangeira (PLE) em alunos hispanofalantes de uma universidade no interior de São Paulo. A análise focaliza as interferências linguísticas nos níveis semântico, sintático e ortográfico. Por meio de princípios do modelo da interlíngua, pertencente à Linguística Contrastiva, procura-se explicar como a língua materna dos alunos hispanofalantes influencia nas produções escritas em língua portuguesa e mostrar quais as interferências linguísticas mais comuns nesses alunos. Ao observar a proximidade tipológica entre português e espanhol, também se aplicou um questionário para compreender o que os alunos hispanofalantes pensam sobre o processo de aprendizagem de uma língua estrangeira próxima à sua língua materna. Sendo assim, investiga-se o que as produções escritas evidenciam sobre as interferências linguísticas na interlíngua e as impressões dos alunos hispanofalantes sobre como aprendem português língua estrangeira. Após discussão sobre a noção 
de interlíngua e a análise dos dados, sendo entrevistas e textos, verificase que existe um número significativo de interferências linguísticas em alunos hispanofalantes de português, mesmo em um contexto de imersão, pois sua língua materna, espanhol, parece influenciar de modo negativo a aprendizagem de português.

Palavras-chave: interferências linguísticas; interlíngua; português como língua estrangeira; hispanofalantes.

Abstract: This work studies how linguistic interferences occur in interlanguage in native Spanish-speaking learners of Portuguese as a foreign language at a university in São Paulo. The analysis focuses on linguistic interferences at semantic, syntactic and orthographic levels. This study, based on interlanguage modelling of Contrastive Linguistics, aims at explaining how learners' native language influences in the writings in Portuguese as well as showing their most common linguistic interferences. By observing the typological proximity between Portuguese and Spanish, a questionnaire was administered to these learners so as to understand what they think about the process of learning a foreign language that has cross-linguistic similarity to their native language. Therefore, this paper investigates evidences of linguistic interferences in interlanguage, and the impressions of native Spanish-speaking learners about their learning process of Portuguese as a foreign language. After discussing the notion of interlanguage and analyzing the data from the questionnaire and the written compositions, it is verified that there is a significant number of linguistic interferences in the linguistic output of these native Spanish-speaking learners of Portuguese even in immersion context, since Spanish, their native language, seems to influence negatively their learning of the Portuguese language.

Keywords: linguistic interferences; interlanguage; Portuguese as a foreign language; native Spanish speakers.

Recebido em: 03 de maio de 2016. Aprovado em: 08 de agosto de 2016. 


\section{Introdução}

Este trabalho originou-se a partir da importância que tem o ensino de português como língua estrangeira (PLE) no Brasil a imigrantes e alunos hispanofalantes que estudam em diversas universidades brasileiras por meio de constantes intercâmbios estudantis. Graças ao rápido desenvolvimento do Brasil nestes últimos anos, a sua participação na criação do Mercosul e no grupo dos BRICS (Grupo político de cooperação entre Brasil, Rússia, Índia, China e África do Sul) surgiu o aumento de estudantes no território nacional brasileiro, provenientes de países hispanofalantes de América do Sul e da Espanha, assim como de outros países do mundo (Ásia, Europa), para realizar diversos cursos no Brasil e se formar tanto na graduação como na pós-graduação em distintas áreas acadêmicas. Especificamente quanto aos falantes de espanhol, segundo um estudo estatístico, existem 410.000 hispanofalantes de domínio nativo e, 96.000 hispanofalantes de competência limitada no Brasil (INSTITUTO CERVANTES, 2014). Assim, a relevância do conhecimento do português não se limita a seu uso no território brasileiro, mas também além fronteiras, pois a língua portuguesa tem se tornado importante no exterior em virtude da criação de novos espaços para a sua circulação (ZOPPI FONTANA e DINIZ, 2008). Portanto, considera-se fundamental entender os problemas de aprendizagem mais frequentes nesses aprendizes de PLE, uma vez que no Brasil existe um número significativo de estudantes estrangeiros, falantes nativos de espanhol.

Em consequência do aumento de aprendizes hispanofalantes de PLE no Brasil, o objetivo deste trabalho é apresentar uma reflexão teóricoprática sobre as interferências linguísticas que surgem na aprendizagem do português em alunos hispanofalantes, verificando que, geralmente, eles tendem a seguir as normas linguísticas da sua língua materna (LM), espanhol, para realizar as produções escritas devido à proximidade tipológica entre português e espanhol. Assim, leva-se em conta que tais interferências podem ser fontes constantes de erros sistemáticos na aprendizagem de uma língua estrangeira (LE), notadamente, de línguas próximas como o português e o espanhol. Como afirma Lado (1973), um aluno tende a transferir as formas e os significados da sua própria língua e cultura, assim como a distribuição destas formas e os significados à língua e à cultura estrangeira, não somente ao tentar falar o idioma e 
se desenvolver na mesma cultura, mas também ao tentar compreender a língua e a cultura segundo como os falantes nativos que as praticam.

Com relação ao suporte teórico, apoia-se este estudo sobre as interferências linguísticas com base no modelo da interlíngua, pertencente à Linguística Contrastiva, dado que a interlíngua é entendida como um sistema aproximado que ocorre em uma etapa intermediária susceptível de modificações e reestruturações do input do aprendiz (SELINKER,1972). Desse modo, o estudo desse fenômeno linguístico possibilitou ampliar a análise das interferências linguísticas no nível semântico, sintático e ortográfico identificadas nas produções escritas dos alunos hispanofalantes de PLE. À vista disso, Almeida Filho (2001) assevera que o portunhol, termo usado para designar a produção linguística de nível intermediário de hispanofalantes ao tentarem falar português, surge da interlíngua que se desenvolve na aprendizagem de PLE naqueles aprendizes. Assim, o estudo da interlíngua é importante para evidenciar e entender problemas existentes durante a aprendizagem de uma LE, no nosso caso, de línguas próximas: português e espanhol.

Deste modo, por meio da análise das redações escritas, objetivase identificar as interferências linguísticas no processo de produção da interlíngua em alunos estrangeiros hispanofalantes, de graduação e pós-graduação, que frequentam curso presencial de PLE no nível intermediário, em uma universidade brasileira localizada no interior do Estado de São Paulo e que estão em situação de imersão, e podese evidenciar dados relevantes que proporcionam uma contribuição significativa aos estudos sobre ensino e aprendizagem de PLE tanto para esses aprendizes como para promover a redução de desvios da norma culta nos campos linguísticos focalizados.

Finalmente, com o propósito de realizar uma reflexão sobre a representação que os alunos hispanofalantes têm sobre a aprendizagem de PLE, especificamente, sobre como influencia a proximidade tipológica entre português e espanhol, aplicou-se um questionário sobre qual o papel da LM durante o processo de aprendizagem de PLE. De modo geral, pôdese verificar nas respostas dos alunos, na análise destas e de suas redações que o espanhol ainda está presente e influenciando a produção de textos em português, reiterando a presença de uma interlíngua nesses alunos hispanofalantes. Deste modo, entende-se que a maioria das interferências linguísticas é originada da LM, espanhol, o que pode dificultar o processo de aprendizagem da nova língua, português. 
Sendo assim, passa-se ao aporte teórico que sustenta este estudo, ou seja, interlíngua e interferências.

\section{Interlíngua}

Com o objetivo de revisar a literatura sobre Linguística Contrastiva (LC) em especial sobre a Interlíngua (SELINKER, 1972), tanto para fundamentar o construto epistêmico como para proceder a análise neste estudo, recupera-se, a seguir, os teóricos que versaram sobre o tema.

A proposição de modelos de análise baseados na LC abrange o estudo da interlíngua. Assim, para entender o conceito de interlíngua, pretende-se definir primeiro a LC, com o propósito de contextualizar o estudo. De acordo com Trager (1949), o termo "linguística contrastiva" foi utilizado como subdisciplina da linguística aplicada, com a finalidade de estudar os traços conflitivos das línguas descrevendo suas gramáticas. Procedendo desta maneira, é possível mostrar quais são as partes da estrutura que dificultam o processo de aprendizagem. Santos Gargallo (1993) afirma que a LC propõe um tipo de investigação baseado na comparação de duas ou mais línguas, a LM do aluno e uma LE. Portanto, a LC faz parte da linguística aplicada e estuda o contraste sincrônico de dois ou mais sistemas linguísticos.

$\mathrm{Na}$ literatura da linguística contrastiva, esta subdisciplina apresenta duas versões de estudo: a linguística contrastiva teórica e a linguística contrastiva prática (SANTOS GARGALLO, 1993). A primeira focaliza seus estudos nas diferenças e semelhanças entre duas ou mais línguas e estabelece um modelo adequado de comparação para determinar quais são os elementos possíveis de comparar. A segunda versão analisa e explica como uma categoria universal acontece em línguas diferentes.

Segunda a autora, a diferença entre essas duas versões está assentada no objetivo final da investigação, isto é, na versão teórica buscase consequências nos universais linguísticos e se comparam mais de duas línguas, enquanto a versão prática procura, além de realizar e explicar as diferenças e as semelhanças entre duas línguas, aplicar seus resultados ao processo de ensino e aprendizagem da LE como sua finalidade.

Além disso, a autora analisa os três modelos teóricos da linguística contrastiva: o modelo de análise contrastivo (AC), o modelo de análise de erros (AE) e o modelo de interlíngua (IL). Para ela, o modelo de AC 
prediz erros; o modelo de AE classifica, cataloga e analisa os erros; e o modelo de IL indica que nível de aprendizagem o aluno apresenta por meio do tipo de erros. Em relação ao modelo da interlíngua, o presente trabalho procurou identificar e estudar as interferências linguísticas por meio das análises das produções escritas de alunos hispanofalantes de PLE em contexto de imersão.

Uma vez sabendo como surgiu a análise da interlíngua, o próximo passo é explicar o conceito desse modelo que foi introduzido pela primeira vez por Selinker (1972), entendendo-o com um sistema caracterizado pela variabilidade e sistematicidade que apresenta processos centrais, os quais fazem parte da base teórica para a análise das interferências linguísticas nos alunos hispanofalantes de PLE.

Segundo este investigador norte-americano, a maioria dos aprendizes ativa na mente uma estrutura psicológica latente quando tenta produzir ou entender um enunciado em uma LE. Essa estrutura se realiza no sistema independente, que o autor chama de Interlíngua. Segundo o pesquisador, o estudo da interlíngua pode ser efetuado a partir de processos como: transferência linguística, transferência de instrução, estratégias de aprendizagem, estratégias de comunicação e hipergeneralização do material linguístico da LE.

A transferência linguística acontece quando as regras e subsistemas, desenvolvidos na interlíngua, procedem da LM. Enquanto que na transferência de instrução essas regras e subsistemas são o resultado de processos de instrução ou ensino. Se essas regras sucedem da aproximação do aluno com o material de estudo, trata-se do processo de estratégias de aprendizagem, e se resultam da aproximação do aluno com a língua, para se comunicar com falantes nativos da LE, trata-se das estratégias de comunicação. Finalmente, quando acontece uma hipergeneralização, ou seja, quando se toma uma regra específica para generalizar casos de outras regras semelhantes linguisticamente da LE, trata-se do processo de hipergeneralização do material linguístico da LE.

Do mesmo modo, a interlíngua é conhecida como o "sistema aproximado". Trata-se de um sistema linguístico utilizado pelo aprendiz, durante seu processo de aprendizagem de uma LE. O falante recorre a esse sistema aproximado para se exprimir na língua meta. Tal sistema tem uma gramática própria que não é a da LE nem a da LM, modificandose rapidamente ao passar por diferentes etapas da aquisição (NEMSER 1971). 
Corder (1973), por sua vez, utiliza o termo "competência transitória" ou "dialeto idiossincrático" para se referir à interlíngua e, assim como Nemser, também afirma ser um sistema com regras próprias, contudo, marcado pela instabilidade. Em outras palavras, Corder entende que a língua do aprendiz não é necessariamente o código de nenhum grupo social; enquanto o aluno está no processo de aprendizagem, não existe uma constância em seu dialeto.

Isto posto, Corder estabelece que o fenômeno da interlíngua se refere a um sistema interlinguístico do qual o aprendiz faz uso, e em que aparecem tanto as reduções como as simplificações do código da LE. Corder expõe, ainda, que o aluno de uma LE utiliza um reduzido número de palavras gramaticais, utiliza estruturas sintáticas simples e um léxico altamente polissêmico. Portanto, nesta perspectiva o objetivo do pesquisador deve ser o de identificar e analisar as expressões idiossincrásicas produzidas pelos alunos, buscando a explicação de sua produção.

Segundo Corder, existem quatro etapas da interlíngua na análise de erros. A primeira é a pré-sistemática, caracterizada por ser uma etapa inicial de experimentação da língua, em que se constroem hipóteses de acordo com os dados a que se tem acesso. Na segunda etapa, a emergente, há o início do discernimento e assimilação de regras da LE; todavia, embora possua um conhecimento linguístico, o aprendiz ainda não consegue corrigir os próprios erros. Na terceira, denominada etapa sistemática, o aprendiz é capaz de se corrigir quando os erros são apontados por outras pessoas, revelando, assim, um conhecimento mais estruturado da língua. A etapa final, denominada etapa de estabilização, caracteriza-se pela ocorrência de poucos erros na produção do aprendiz, não havendo a necessidade da retroalimentação. Nessa fase, o aprendiz se autocorrige.

Para Ellis (1989), quando o aluno recorre à interlíngua significa que à medida que os aprendizes adquirem mais conhecimentos sobre a LE, eles reestruturam o sistema linguístico da LE podendo haver um aumento de uso de regras gramaticais e a eliminação de outras regras na LE. Sendo assim, a interlíngua é um sistema variável que surge da necessidade do aprendiz de ter acesso aos dados da LE e, consequentemente, de comunicar-se nessa língua, recorrendo a esse sistema interiorizado. 
Para o autor, na interlíngua ocorre tanto a sistematicidade como a variabilidade. Desse modo, a interlíngua é sistemática por possuir conjuntos de regras que vão sendo construídos, sendo variáveis na medida em que há uma reorganização linguística constante. Assim, é composta por duas grandes fases: uma de alta variabilidade, que acontece depois de alguns anos, e outra de estabilização, que é atingida quando o aprendiz já passou pelas etapas do processo de aprendizagem, e já experimentou suas hipóteses sobre a LE, atingindo uma etapa de estabilização na qual há poucas mudanças na produção.

Por sua vez, Santos Gargallo (1993) menciona que a interlíngua se refere ao sistema não nativo do aprendiz de uma LE, pois esse sistema constitui uma língua autônoma. À vista desse conjunto linguístico utilizado pelo aprendiz, Santos Gargallo (1999, p.28) afirma que a interlíngua é:

Um sistema que possui traços da língua materna e outros propriamente idiossincrásicos, e cuja complexidade vai se incrementando em um processo criativo que atravessa sucessivas etapas marcadas pelos novos elementos que $o$ falante interioriza. ${ }^{1}$

Dessa forma, a autora explica que a interlíngua do aprendiz sempre estará subordinada a sua intenção de estabelecer e manter a conversação na LE. Ao levar em conta esse fato, o aprendiz estará sujeito a buscar solução a problemas de caráter comunicativo usando recursos linguísticos ou não linguísticos para remediar as carências linguísticas que ele apresenta. $\mathrm{O}$ objetivo final da comunicação é a compreensão da mensagem transmitida pelo aprendiz ao interlocutor nativo ou não nativo da LE, portanto, a linguista espanhola defende que se as produções linguísticas realizadas pelos alunos conseguem ser decodificadas, significa que a interlíngua desse aluno tem funcionado.

Um estudo muito relevante que trata sobre a interlíngua, é realizado por Fernández (1997), que resume o conceito da interlíngua em uma etapa necessária que aparece e persiste obrigatoriamente no processo de aprendizagem do aluno. Seus traços essenciais são manifestados por

\footnotetext{
${ }^{1}$ Un sistema que posee rasgos de la lengua materna y otros propiamente idiosincrásicos, y cuya complejidad se va incrementando en un proceso creativo que atraviesa sucesivas etapas marcadas por los nuevos elementos que el hablante interioriza. (Todas as traduções pertencem aos autores).
} 
meio da diferença que marca este sistema aproximado da LM e da LE, com suas próprias regras e com sua variabilidade e evolução. Fernández afirma que a investigação sobre a interlíngua surge com a apresentação e a análise do erro, e, sobretudo, com a preocupação do professional por buscar um rumo para ensinar a superação desse dialeto idiossincrático. Em relação ao papel da interlíngua e o conceito do erro, Fernández (1997, p. 14) assevera que:

Da Assunção dos erros como índices das etapas pelas quais o aprendiz atravessa no percurso da apropriação da língua-alvo, passa ao conceito de "interlíngua" (IL), como o sistema próprio de cada uma dessas etapas. A análise da IL nasce apoiando-se na análise de erros, mas logo amplia seu campo de observação, dado que nesse "sistema aproximado" existem estruturas diferentes às da línguaalvo - as formas "errôneas" -, mas também se produzem muitas estruturas corretas de acordo com a norma da nova língua. ${ }^{2}$

Baralo (1999) também aborda o fenômeno da interlíngua em seus estudos. A autora, assim como Fernández, afirma que o principal motivo do estudo da interlíngua é a preocupação dos professores em utilizar critérios metodológicos adequados cuja aplicação ofereça aos alunos de LE mecanismos para evitarem o erro. Esses erros acontecem quando as estruturas e as formas linguísticas da LE ainda não estão interiorizadas no aluno. Baralo declara que o fenômeno da interlíngua está intrinsecamente relacionado ao modelo teórico-prático da Análise de Erros. Assim, essa metodologia se baseia em interpretar o erro, não somente como uma consequência da transferência da LM, mas também como resultado de causas intralinguais, referidas ao próprio processo de aprendizagem do novo sistema linguístico. Para a autora, os estudos da interlíngua são importantes, pois permitem obter um panorama detalhado e expressivo do desenvolvimento do sistema idiossincrático, e auxiliam

\footnotetext{
${ }^{2}$ De la Asunción de los errores como índices de los estadios por los que el aprendiz atraviesa en el camino de apropiación de la lengua meta, se pasa al concepto de "interlengua" (IL), como el sistema propio de cada uno de esos estadios. El análisis de la IL nace apoyándose en el análisis de errores, pero pronto alarga su campo de observación, ya que en ese "sistema aproximado" existen estructuras diferentes a las de la lengua meta - las formas "erróneas" -, pero también se producen muchas estructuras correctas de acuerdo con la norma de la nueva lengua.
} 
na compreensão dos problemas inerentes ao processo de aprendizagem de uma LE, de modo a proporcionar aos educadores a possibilidade de adoção de técnicas de ensino mais adequadas, que possam ajudar os alunos a superarem suas dificuldades com a nova língua.

Baralo (2003) menciona que o construto teórico da interlíngua tem se desenvolvido paralelamente com a evolução da teoria linguística e das teorias de aquisição e aprendizagem de línguas. Os estudos sobre a interlíngua tentam descobrir o que acontece na mente do aprendiz, como se processam, são usados e dispostos os dados linguísticos nas produções textuais dos educandos. Ademais, Baralo afirma que na construção do conhecimento interlinguístico intervêm três processos básicos, três abordagens teóricas específicas em relação à aprendizagem e ao ensino, a saber: o input, o intake, o output. O input é o processo da entrada de dados externos com os quais o aprendiz tem contato e que são selecionados, ordenados e sistematizados; o intake se refere ao processo de incorporação dos novos dados ao sistema, os quais o aprendiz assimila e organiza; e o output é o processo de saída, que permite ao aprendiz compreender e se exprimir na LE.

Segundo a autora, quanto ao construto dos modelos cognitivos, os processos da interlíngua têm sido interpretados como processos de aprendizagem por meio de comprovação de hipóteses. Assim, o aluno formula hipóteses sobre as propriedades estruturais da LE a partir dos dados do input que ele recebe. Ele pode construir uma gramática hipotética que é testada por meio da compreensão e a produção ao verificar se as respostas interlinguísticas são plausíveis e aceitas pelos interlocutores, sem comentários nem mal-entendidos. Se frustrada a intenção comunicativa, o aprendiz tem a oportunidade de reestruturar as hipóteses sempre e quando ele estiver motivado.

Uma análise mais contemporânea acerca da interlíngua é realizada por Durão (2007), para quem esse fenômeno é um continuum linguístico, que para ser atravessado é necessário o tempo. Essa meta depende das características dos próprios alunos, ou seja, de suas aspirações, de sua LM, e se dominam mais LEs. A autora menciona que existem dois extremos: de um lado, a LM e as outras línguas não nativas; de outro, a LE em processo de aprendizagem. Por conseguinte, o percurso que o aluno deve fazer de um extremo ao outro coincide com o conhecimento que ele deve adquirir sobre a nova língua, baseando-se em sua própria LM ou em outras LEs aprendidas anteriormente. Os novos elementos 
que são adicionados aos conhecimentos prévios do aluno, ocasionam também experiências de uso. Assim, o aluno deve superar distintas etapas ou obstáculos que a autora chama de "barreiras", "dificuldades de aprendizagem" e "plataformas de resistência". Em relação a todas essas características da interlíngua, Durão (2007, p.31) conclui que:

Todas e cada uma das etapas da aprendizagem pelas quais os aprendizes terão que passar ao atravessar a passarela deixarão evidências dos traços da interiorização das regras da língua em questão (desenvolvidas com ou sem atitude) e ajudarão a identificar a etapa de sua interlíngua, isto é, o nível de aprendizagem conseguido. ${ }^{3}$

Para a autora, os estudos da interlíngua abrangem, principalmente, a aprendizagem do conhecimento da LE, as teorias que explicam como os alunos constroem a representação mental da LE, como se desenvolve o conhecimento das regras e dos itens da LE. Portanto, esses estudos se referem ao conhecimento do aluno, ou seja, ao sistema operativo abstrato de unidades e regras combinatórias que subjaz ao uso real desse conhecimento.

À guisa de conclusão, a interlíngua se refere às etapas pelas quais o aprendiz percorre antes de atingir sua meta ao aprender uma LE, isto é, a fluência comunicativa adequada em LE (FERNÁNDEZ, 1997), de acordo com seus objetivos traçados e contexto ao qual estará inserido. $\mathrm{O}$ estudo da interlíngua tem como objetivo demostrar que os erros não são fortuitos, e, portanto, intenciona descrever o sistema de regras presentes no aprendiz quando este tenta se comunicar em uma LE. Deste modo, este estudo pretende iluminar a análise dos dados levantados segundos os aportes de Selinker, sobre conceito de interlíngua e seus processos; de Durão no que se refere à questão da reestruturação na aprendizagem de LE e de Corder com relação às etapas da interlíngua, contribuindo, assim, tanto na aprendizagem de PLE por hispanofalantes como no ensino de PLE em geral.

\footnotetext{
${ }^{3}$ Todas y cada una de las etapas del aprendizaje por las que los aprendices tendrán que pasar al cruzar la pasarela dejarán evidencias de las huellas de la interiorización de las reglas de la lengua en cuestión (desarrolladas con o sin actitud) y ayudarán a identificar el estadio de su interlengua, es decir, el nivel de aprendizaje conseguido.
} 


\section{Interferências linguísticas}

Para entender o conceito de interferência linguística é necessário salientar que o estudo deste termo baseia-se na teoria behaviorista. Esta teoria pressupõe que os indivíduos não possuem habilidades inatas, mas sim propensões para responder aos estímulos aos quais estão expostos. Assim, com a resposta de cada estímulo se desenvolveriam comportamentos. Deste modo, Watson (1913) postulou que cada resposta a um estímulo pode ser reforçada de maneira positiva ou negativa. $\mathrm{O}$ reforço positivo acontece quando uma resposta tem como resultado um benefício. Portanto, o reforço negativo acontece quando aquela resposta não contribui a nenhum benefício.

Sousa (2002) assevera que a teoria behaviorista entende o fenômeno da transferência linguística como fator de aprendizagem e que é afetado pela semelhança entre o conhecimento prévio e o subsequente. De acordo com esta teoria, estabelecem-se dois tipos de transferência linguística no âmbito de aprendizagem: a transferência linguística positiva e a transferência linguística negativa, mais conhecida como a interferência linguística. Segundo Lado (1957), a transferência linguística positiva se refere ao uso produtivo da LM no desempenho da LE, sendo o resultado das semelhanças entre a LM e a LE.

Dessa forma, a interpretação de interferência linguística baseiase sob a óptica de dois elementos que se alteram como consequência do contato linguístico, e, sobretudo na circunstância de que um traço alheio se introduz em um código ou no uso que se faz deste código. Por um lado, a interferência é considerada como um processo e possui distintas fases. Weinreich (1953) estabelece duas fases: a interferência na fala, que afeta aos indivíduos bilíngues e se produz no momento da situação comunicativa; e a interferência na língua, interferência que está integrada no sistema e que não faz parte unicamente da fala dos bilíngues, mas que tem sido incorporada pelos indivíduos monolíngues.

Por outro lado, o autor propõe outra perspectiva de estudo ao tratar a interferência linguística como resultado e não como processo, ou seja, fazer uma análise de maneira isolada de cada uma das formas "interferidas" em relação à estrutura "interferente". Este linguista estabelece quatro casos unicamente para a interferência fonológica: hipodiferenciação de fonemas, hiperdiferenciação de fonemas, reinterpretação de distinções, e substituição de fonemas. Por sua vez, Payrató (1985) faz extensivo 
este esquema aos níveis gramatical e lexical, e adiciona os fenômenos de importação e perda.

Em consequência, Overbeke (1976) oferece uma classificação da interferência linguística a partir de diferentes pontos de vista, estabelecendo dez relações binárias: interferência como processo/ interferência como resultado; interferência proativa/interferência retroativa; interferência que afeta o código/interferência que afeta os comportamentos sociolinguísticos; interferência de formas libres/ interferência de formas obrigatórias; interferência segmental/interferência suprassegmental; interferência na primeira articulação/interferência na segunda articulação; interferência gramatical/interferência lexical; interferência morfológica/interferência sintática; interferência interlinguística/interferência intralinguística; interferência denotativas/ interferência conotativa.

Percebeu-se que não existe uma única unidade de critério para a classificação das interferências, provavelmente porque é um fenômeno no qual estão envolvidos muitos fatores e se torna impossível trabalhar a partir uma única perspectiva. No entanto, existe um ponto em comum nas classificações de todos os autores mencionados anteriormente, pois direta ou indiretamente as interferências estão relacionadas com a divisão metodológica própria do sistema da língua nos quatro níveis básicos: fonológico, lexical, morfológico e sintático.

Por outro lado, os níveis linguísticos não são compartimentos estanques, a língua é dinâmica e, em consequência, os fenómenos linguísticos como a interferência, atravessam continuamente as fronteiras entre um e o outro, portanto, resulta difícil afirmar que se envolve unicamente um nível linguístico, pois na maioria dos casos existem implicações em mais de um nível. Assim sendo, Baetens (1986) afirma que a fronteira entre a morfologia, a sintaxe e o léxico não é jamais uniforme e às vezes as interferências só podem ser explicadas cruzando as barreiras entre os distintos níveis da análise linguística.

Por conseguinte, segundo as asserções de Weinreich (1953), Overbeke (1976) e Baetens (1986), a interferência linguística se refere aos casos de desvio da norma de qualquer das línguas de uma comunidade bilíngue devido ao contato linguístico. Nesta definição, a norma é entendida não somente como aquela que procede das instituições que estão a cargo de criar regras sobre a língua, mas também com o uso habitual da língua. 
Desta forma, este trabalho analisa as interferências linguísticas na interlíngua com base no último conceito mencionado, isto é, casos de desvio da norma devido ao contato linguístico entre a LM (o espanhol) e a LE (o português) em alunos hispanofalantes de PLE. De acordo com o exposto, as interferências linguísticas estão analisadas no nível semântico, sintático e ortográfico, de modo separado por questões didático-metodológicas, promovendo a compreensão das interferências e a reflexão sobre estas relações.

\subsection{Interferência no nível semântico}

A importância do nível semântico está no fato de ser um campo linguístico, no qual os alunos costumam apresentar dificuldades em diferenciar no processo de ensino e aprendizagem de PLE, a língua portuguesa da língua espanhola, provavelmente por existir muitos cognatos e falsos cognatos entre estas duas línguas próximas.

Primeiramente, faz-se necessário distinguir quando a interferência afeta unicamente a forma ou quando afeta o significado. Portanto, o estudo das interferências neste nível linguístico se classifica em: semântica proposicional e semântica lexical (Odlin, 1997, p.71). A semântica proposicional investiga as mudanças existentes nos significados de sintagmas, proposições ou orações. A semântica lexical estuda as mudanças que acontecem nos significados das palavras, e este, por sua vez, se classifica em: estudo do léxico e estudo morfológico.

Quando se analisa o caso concreto do contato espanhol-português, sendo estas duas línguas tão próximas, resulta difícil, às vezes, distinguir se o léxico pertence a uma ou a outra língua (Atienza et al., 1996). À vista disso, podem ser notadas palavras que são casos claros de interferência e cuja semelhança formal dificulta a aplicação de um termo que indique com clareza o fenômeno.

\subsection{Interferência no nível sintático}

Blas Arroyo (1993) alega ser a interferência sintática como aquela que está relacionada às estruturas dentro da oração. $\mathrm{O}$ autor afirma que a interferência sintática é pouco estudada em comparação com a interferência semântica ou à interferência fônica, provavelmente porque o nível sintático é o mais estruturado, e, portanto, o mais difícil de sofrer alteração. Em contrapartida, é mais complexo estudar a variação sintática 
em textos orais ou escritos que estudar os sons ou o léxico, razão pela qual esses estudos foram realizados em poucas ocasiões. Isso significa que o nível em voga experimenta pouca variação na interlíngua.

Em geral, considera-se que este campo linguístico não é alvo de muitos erros em alunos hispanofalantes de PLE, o português e o espanhol apresentam uma sintaxe muito parecida. No entanto, neste estudo julgouse necessário apresentar os casos mais comuns das interferências neste nível linguístico para fins de melhor compreender o desenvolvimento da interlíngua nos alunos.

\subsection{Interferência no nível ortográfico}

Atienza et al. (1996) analisam questões de ortografia, mantendo dois grandes blocos que tradicionalmente se distinguem neste âmbito a "acentuação", na qual se observam interferências em razão da norma escrita e da pronúncia do espanhol, das "grafias" propriamente ditas, em que se distinguem interferências provocadas por confusão de grafias, assim como interferências ocasionadas pela confusão na segmentação de algumas unidades (p.52). Cogitou-se, aqui, em estudar este campo linguístico porque existe pouca literatura que trata da ortografia no âmbito de ensino e aprendizagem de LEs, notadamente na área de PLE para hispanofalantes.

\section{Metodologia}

Os dados constituintes deste estudo foram coletados na Universidade Estadual Paulista "Júlio de Mesquita Filho", câmpus de Araraquara, no curso de Português como Língua Estrangeira para alunos estrangeiros, especificamente em hispanofalantes de graduação e pósgraduação da área de Letras, Ciências Sociais, Farmácia, Química e Odontologia.

Este trabalho teve como instrumentos de análise: a) um questionário aplicado no final do curso que trata do papel da LM durante o processo de aprendizagem de PLE, e b) material escrito e produzido pelos alunos hispanofalantes, que frequentavam aulas de PLE no nível intermediário durante os primeiros meses do curso. Considerou-se este período como a etapa inicial do nível intermediário, fator que poderia ter maior ocorrências de interferências de espanhol na aprendizagem de português. O material escrito compõem-se de dois textos argumentativos 
solicitados aos alunos de PLE sobre os temas que se estavam trabalhando nas aulas, totalizando 20 redações. Cada aluno realizou dois textos argumentativos cujos temas foram os seguintes:

- Trabalhar em casa versus trabalhar no escritório.

- Vantagens e desvantagens de morar no exterior.

Quanto à metodologia, este estudo foi desenvolvido seguindo as análises qualitativa e quantitativa. Realizaram-se gráficos estatísticos para a análise das interferências linguísticas e para o questionário aplicado aos alunos. Além disso, para a análise das interferências linguísticas, as análises qualitativa e quantitativa são subsidiadas pelo critério frequência, nos moldes de Bybee (2006). Para esta autora, há dois métodos relevantes para constatar a frequência, a frequência token e a type. A frequência token refere-se à frequência textual de ocorrência de um item/construção independentemente do seu significado. A frequência type refere-se à frequência com que um padrão particular ocorre, sendo avaliada por meio das funções assumidas pelo item ou construção.

Com base na definição da interferência linguística (WEINREICH, 1953), as interferências linguísticas são divididas em três níveis: semântico, sintático e ortográfico. Por conseguinte, é necessário esclarecer que neste trabalho considera-se relevante tratar tanto da frequência token como da frequência type. Ao classificar as interferências linguísticas, a frequência token refere-se à contagem geral das interferências linguísticas existentes em cada um dos níveis: semântico, sintático, ortográfico. Nesse sentido, a frequência type é obtida por meio da análise e quantificação dos diferentes construtos linguísticos identificados nas interferências linguísticas, a saber, semânticas, sintáticas e ortográficas.

\section{Análise dos dados}

Nesta pesquisa identificaram-se um total de 119 (cento e dezenove) interferências linguísticas. A análise teve como foco as interferências no nível semântico, sintático e ortográfico identificadas na interlíngua dos alunos hispanofalantes de PLE em contexto de imersão.

Observa-se a seguir a frequência token: 
TABELA 1

Frequência token das interferências linguísticas identificadas nas produções escritas

\begin{tabular}{ccc}
\hline INTERFERENCIAS LINGUÍSTICAS & FREQUÊNCIA & PORCENTAGEM \\
\hline Interferência linguística no nível semântico & 21 & $9 \%$ \\
Interferência linguística no nível sintático & 33 & $16 \%$ \\
Interferência linguística no nível ortográfico & 65 & $75 \%$ \\
TOTAL & 119 & $100 \%$ \\
\hline
\end{tabular}

A partir dos valores mostrados na tabela, é possível observar nos alunos hispanofalantes, em sua aprendizagem de português em contexto de imersão, uma forte tendência à interferência no nível ortográfico, o que pode significar um problema grave na escrita, pois tanto a acentuação quanto a grafia da língua portuguesa podem estar comprometidas.

Com a intenção de explicar as ocorrências de interferências linguísticas presentes na interlíngua desses alunos, mostram-se em seguida as análises de acordo com sua classificação, a saber, interferências semânticas, sintáticas e ortográficas. Logo, passa-se a realizar a interpretação do questionário aplicado aos alunos hispanofalantes que trata sobre o papel da LM na aprendizagem de PLE.

\subsection{Interferências no nível semântico}

Neste nível linguístico foram identificadas 21 (vinte e uma) interferências semânticas nas produções escritas dos alunos. As análises realizaram-se com base na classificação de Odlin (1997), ou seja, semântica proposicional e semântica lexical. Veja-se a seguir:

\section{TABELA 2}

Frequência type dos construtos linguísticos das interferências semânticas

\begin{tabular}{ccc}
\hline NIVEL SEMÂNTICO & FREQUENCIA & PORCENTAGEM \\
\hline Falso cognato & 14 & $67 \%$ \\
Versão literal & 4 & $17 \%$ \\
Palavra homófona & 3 & $16 \%$ \\
TOTAL & 21 & $100 \%$ \\
\hline
\end{tabular}


Nas interferências semânticas apresentam-se três construtos linguísticos identificados nas redações dos alunos. Em primeiro lugar, o falso cognato que acontece quando palavras da LM e da LE têm semelhança ortográfica, mas diferem completa ou parcialmente quanto ao significado. Em segundo lugar, a palavra homófona que ocorre quando uma palavra da LM ou da LE se pronunciam de forma quase idêntica a outra palavra da LE dificultando entender o significado da palavra que realmente deve ser utilizada no contexto. Em terceiro lugar, a versão literal que trata quando os alunos traduzem palavra por palavra da LM para a LE, assim, existe a dificuldade de compreensão por não haver tal estrutura na LE.

\section{(1) Falso cognato}

Exemplo:

Texto observado:

Possibilidade em português:

Em espanhol:

Processo de interlíngua

\section{SALUDAR}

Eles sempre abraçam quando a gente saluda

Eles sempre abraçam quando a gente cumprimenta/saúda. Ellos siempre abrazan cuando la gente saluda. Transferência linguística

Trata-se de uma interferência semântica da LM. Este exemplo é um caso de interferência na semântica lexical, pois em espanhol, o verbo SALUDAR ${ }^{4}$ se usa com o sentido de cumprimentar alguém. Em português, temos também o verbo saudar com significado de cumprimentar.

A seguir, um exemplo de versão literal:

\footnotetext{
${ }^{4}$ SALUDAR. In: DICIONÁRIO Michaelis. Disponível em: $<$ http://michaelis.uol.com. br/>. Acesso em: 23 jun. 2015
} 


\section{(2) Versão literal}

$\begin{array}{ll}\text { Exemplo } & \text { OLHAR MAL } \\ \text { Texto observado: } & \begin{array}{l}\text { Nós olhamos mal as pessoas que visten extranho ou com roupa } \\ \text { colorida. }\end{array} \\ \text { Possibilidade em } & \begin{array}{l}\text { Nós temos um olhar preconceituoso para as pessoas que vestem } \\ \text { português: }\end{array} \\ \text { Em espanhol: } & \begin{array}{l}\text { Nosotros vemos mal a las personas que visten extraño o con ropa } \\ \text { colorida. }\end{array}\end{array}$

Processo de interlíngua Transferência linguística

Observa-se que este exemplo trata-se de uma interferência semântica proveniente da LM, sendo um caso de interferência na semântica proposicional. Em espanhol, a expressão VER MAL é usada para se referir a algo ou a alguém com tom depreciativo e é construída com o verbo "ver" seguido do advérbio "mal", assim como em português a expressão SÃO MAL VISTAS ou ainda NÃO SÃO BEM VISTAS, entretanto, o aluno usou a versão literal em português com o emprego do verbo OLHAR MAL. Além disso, pode ser usada ainda outra expressão em português: TER UM OLHAR PRECONCEITUOSO.

\section{(3) Palavra homófona}

Exemplo

Texto observado:

Possibilidade em português:

Em espanhol:

Processo de interlíngua
MAIS

Mais bôm a mia experiencia é ótima.

Mas bom, a minha experiência é ótima.

Pero bueno, mi experiencia es óptima.

Estratégia de comunicação

Trata-se de uma interferência semântica da LE devido à confusão da pronúncia entre as palavras mas, conjunção adversativa, e mais, advérbio de intensidade, em português. Este exemplo é um caso de interferência na semântica lexical, porque houve uma mudança no significado da palavra MAIS. Este caso apresenta surdez fonológica devido a que os alunos hispanofalantes não percebem a diferença entre os fonemas /ais/ da palavra MAIS e os fonemas /as/ da palavra MAS. 
Observa-se também uma transferência da expressão "pero bueno", típica do espanhol, mas não correspondente em português, que expressaria a mesma intenção com a conjunção adversativa "mas", sem o adjetivo "bom". Vale ressaltar que o emprego fonológico da conjunção adversativa e do advérbio de intensidade, mas/mais, em geral não é marcado em todo o território brasileiro, dependendo da variedade de cada região.

\subsection{Interferências no nível sintático}

Neste nível linguístico foram identificadas 33 (trinta e três) interferências sintáticas. A análise foi realizada de acordo com a definição de Blas Arroyo (1993). Veja-se a seguir:

\section{TABELA 3}

Frequência type dos construtos linguísticos das interferências sintáticas

\begin{tabular}{ccc}
\hline NIVEL SINTÁTICO & FREQUENCIA & PORCENTAGEM \\
\hline Omissão de contração & 13 & $38 \%$ \\
Uso incorreto de verbo & 5 & $15 \%$ \\
Uso incorreto de preposição & 4 & $13 \%$ \\
Uso incorreto de adverbio & 3 & $8 \%$ \\
Uso incorreto de plural & 3 & $8 \%$ \\
Uso incorreto de adjetivo & 2 & $6 \%$ \\
Seleção de tempo verbal & 2 & $7 \%$ \\
Uso incorreto de gerúndio & 1 & $5 \%$ \\
TOTAL & 33 & $100 \%$ \\
\hline
\end{tabular}

Apresentam-se oito construtos linguísticos das interferências sintáticas. A omissão de contração ocorre quando não existe a junção de elementos na LE por exemplo, a preposição por com os artigos definidos $o, a$, os, as. A seleção do tempo verbal acontece quando o aluno erra no uso dos tempos verbais na LE, provavelmente por haver uma semelhança ortográfica entre a conjugação de verbos da LM e aquela da LE. Além desses construtos, os alunos realizaram um uso incorreto de verbo, gerúndio, advérbio, adjetivo, preposição e plural na LE, devido notadamente ao uso da norma linguística da LM. 


\section{(1) Omissão de contração}

Exemplo:

Texto observado:

Possibilidade em português:

Em espanhol:

Processo de interlíngua
POR A

Eles têm muito respeto por a diversidade cultural ao contrario da gente na Argentina.

Eles têm muito respeito pela diversidade cultural ao contrário da gente na Argentina.

Ellos tienen mucho respeto por la diversidad cultural al contrario de la gente en Argentina.

Transferência lingüística

Trata-se de uma interferência sintática da LM. Em espanhol, não existe contração da preposição "por" seguida de um artigo definido (el, la, los, las). Em português, a norma exige que aquela preposição seja contraída com os artigos definidos (o, a, os, as) construindo: pelo, pela, pelos, pelas

\section{(2) Uso incorreto de verbo}

Exemplo:

Texto observado:

Possibilidade em português:

Em espanhol:

Processo de interlíngua
VOU A FICAR

Tambem estou gostando muito da comida, vou a ficar gordo no Brasil.

Também estou gostando muito da comida, vou ficar gordo no Brasil.

También estoy gustando mucho de la comida, voy a quedar gordo en Brasil.

Transferência lingüística

Trata-se de uma interferência sintática da LM. Em espanhol, a estrutura gramatical do futuro imediato é constituída da preposição $\boldsymbol{a}$ :

$$
[\mathrm{IR}+\mathrm{A}+\mathrm{VERBO} \text { NO INFINITIVO }]
$$

Em português, o futuro imediato não é constituído da preposição $\boldsymbol{a}$ :

$$
[\text { IR + VERBO NO INFINITIVO }]
$$




\section{(3) Uso incorreto de preposição}

Exemplo:

Texto observado:

Possibilidade em português:

Em espanhol:

Processo de interlíngua
ACOSTUMAR DE

A gente aqui acostuma de comer muito pão.

A gente aqui costuma comer muito pão.

La gente aqui acostumbra a comer mucho pan.

Hipergeneralização do material linguístico de LE

Trata-se de uma interferência sintática da LE. O aluno fez um erro sintático devido à norma em português de colocar a preposição de depois de verbos como: lembrar, esquecer, gostar. No entanto, em português o verbo ACOSTUMAR ${ }^{5}$ se usa com o sentido de fazer adquirir um costume ou habituar, já o verbo COSTUMAR ${ }^{6}$ se usa com o sentido de ter um determinado procedimento habitual ou uma prática constante e é precedido de um verbo no infinitivo. Portanto, o possível equivalente em português é COSTUMAR.

\section{(4) Uso incorreto de advérbio}

Exemplo:

Texto observado:

Possibilidade em português:

Em espanhol:

Processo de interlíngua

\section{PERTAS DE}

Eu espero poder visitar as cidades pertas de Araraquara nos prosimos días.

Eu espero poder visitar as cidades perto de Araraquara nos próximos dias.

Espero poder visitar las ciudades cercanas de Araraquara en los próximos días.

Transferência lingüística

Trata-se de uma interferência sintática da LM. Em espanhol, quase sempre se usa o adjetivo CERCANO que concorda em número e gênero com o substantivo relacionado. Por isso, o aluno criou confusão e

\footnotetext{
${ }^{5}$ ACOSTUMAR. In: DICIONÁRIO Michaelis. Disponível em: < http://michaelis.uol. com.br/>. Acesso em: 23 jun. 2015

${ }^{6}$ COSTUMAR. In: DICIONÁRIO Michaelis. Disponível em: < http://michaelis.uol. com.br/>. Acesso em: 23 jun. 2015
} 
aplicou a mesma regra tentando concordar o advérbio PERTO em gênero feminino e em plural, pois aquele advérbio está seguido do substantivo cidades. Em português, a locução prepositiva "perto de" não sofre flexão de gênero nem de número.

\section{(5) Uso incorreto de plural}

Exemplo:

Texto observado:

\section{LEGALES}

Os brasileiros são muito legales, mas sempre chegam atrasados.

Possibilidade em português: Os brasileiros são muito legais, mas sempre chegam atrasados.

Em espanhol: Los brasileros son muy chéveres pero siempre llegan atrasados.

Processo de interlíngua Transferência linguística

Trata-se de uma interferência sintática da LM. Em espanhol, o adjetivo legal é relativo à lei. $\mathrm{O}$ plural desse adjetivo é construído adicionando "es": LEGALES. No entanto, em português o adjetivo LEGAL $^{7}$ se usa com o sentido de ser de modo agradável e positivo. Assim, a forma correta em plural é LEGAIS.

\section{(6) Uso incorreto de adjetivo}

Exemplo:

Texto observado:

Possibilidade em português:

Em espanhol:

Processo de interlíngua
PAO-DURAS

A gente é pão-duras.

A gente é pão-duro.

La gente es tacaña.

Transferência linguística

Trata-se de uma interferência sintática da LM. Em espanhol, o adjetivo TACAÑO se usa com o sentido de ser avarento ou tacanho e concorda em gênero e número de acordo com o substantivo precedido

${ }^{7}$ LEGAL. In: DICIONÁRIO Houaiss. Disponível em: < http://houaiss.uol.com.br/>. Acesso em: 23 jun. 2015 
(gente). O aluno utilizou o equivalente em português PÃO-DURO. No entanto, este adjetivo é comum de dois gêneros (singular feminino, pãoduro; plural feminino, pães-duros). Além disso, ele cometeu um erro ao colocar em plural esse adjetivo devido ao uso inadequado e comum da discordância de substantivos coletivos em espanhol (geralmente oral), por exemplo:

\section{¿Cómo vivirán esa gente?}

Nessa sentença em espanhol, o substantivo coletivo gente é concordado em plural por tratar-se de várias pessoas e, em geral, as pessoas hispanofalantes fazem o erro de concordar em plural esse substantivo. A sentença correta em espanhol é: ¿Cómo vivirá esa gente?

\section{(7) Seleção de tempo verbal}

Exemplo:

Texto observado:

Possibilidade em português:

Em espanhol:

Processo de interlíngua
FORAM

Eu gostaria que os argentinos foram mais abertos com a gente estrangeira.

Eu gostaria que os argentinos fossem mais amigáveis com a gente estrangeira.

Me gustaría que los argentinos fueran más abiertos con la gente extranjera.

Transferência linguística

Trata-se de uma interferência sintática da LM. Em espanhol, o uso do verbo GUSTAR no tempo condicional é seguido do pretérito imperfeito do subjuntivo:

Me gustaría que los argentinos fueran más abiertos con la gente extranjera.

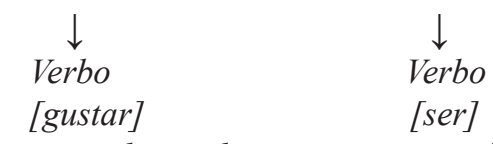

tempo: condicional tempo: pretérito imperfeito do subjuntivo

Em espanhol, a conjugação do verbo "ser" no pretérito imperfeito do subjuntivo da terceira pessoa do plural FUERAN é similar à escrita da conjugação do verbo "ser" no pretérito perfeito da terceira pessoa do plural 
em português FORAM. Essa semelhança interferiu na seleção do tempo verbal adequado para o contexto da frase produzida pelo aluno na LE.

\section{(8) Uso incorreto de gerúndio}

Exemplo:

Texto observado:

Possibilidade em português:

Em espanhol:

Processo de interlíngua

\section{CURTIENDO}

Eu estou curtiendo muito o Brasil.

Eu estou curtindo muito o Brasil.

Estoy disfrutando mucho Brasil.

Transferência linguística

Trata-se de uma interferência sintática da língua materna. Em espanhol, o gerúndio dos verbos terminados em "ir" se usa com a terminação IENDO, enquanto, em português os verbos terminados em "ir” se usa com a terminação INDO.

\subsection{Interferências no nível ortográfico}

Identificaram-se um total de 65 (sessenta e cinco) interferências ortográficas nas produções escritas dos alunos. Realizou-se a análise de acordo com a classificação de Atienza et al. (1996): acentuação e grafias.

\section{TABELA 4}

Frequência type dos construtos linguísticos das interferências ortográficas

\begin{tabular}{ccc}
\hline NÍVEL ORTOGRÁFICO & FREQUENCIA & PORCENTAGEM \\
\hline Troca de grafema & 36 & $56 \%$ \\
Omissão de grafema & 10 & $15 \%$ \\
Acréscimo de grafema & 5 & $8 \%$ \\
Omissão de acento & 11 & $17 \%$ \\
Acréscimo de acento & 2 & $3 \%$ \\
Palavras da língua materna & 1 & $1 \%$ \\
com grafia da língua estrangeira & & $100 \%$ \\
\hline
\end{tabular}


No nível ortográfico apresentam-se seis construtos linguísticos de interferências. Quanto aos grafemas, identificaram-se casos de troca, acréscimo e omissão de grafema na LE devido a que o aluno recorreu à ortografia das palavras equivalentes na LM ou à construção de palavras em português que se escrevem de uma forma semelhante nessa LE. Em relação aos acentos, observaram-se casos de omissão e acréscimo de acento em palavras da LE, pois quase sempre os alunos fizeram uso da norma de acentuação do espanhol. No entanto, poucos casos nesse nível linguístico, acentuação, foram observados, possivelmente devido a uma incorreta aplicação da norma de acentuação da língua portuguesa.

\section{(1) Troca de grafema}

Exemplo:

Texto observado:

Possibilidade em português:

Em espanhol:

Processo de interlíngua

\section{FACEM}

No Brasil os mininos facem muito exercício.

No Brasil os meninos fazem muito exercício.

En Brasil los chicos hacen mucho ejercicio.

Transferência linguística

Trata-se de uma interferência ortográfica da LM. Em espanhol, a conjugação do verbo "hacer" no tempo presente da terceira pessoa do plural é HACEN. Observa-se que se utiliza o grafema $c$. Em português, na conjugação do verbo "fazer" no tempo presente da terceira pessoa do plural FAZEM se utiliza o grafema " $z$ ". Portanto, o aluno utilizou a norma de conjugação do verbo "hacer" em espanhol para a conjugação do verbo "fazer", o equivalente em português.

\section{(2) Troca de grafema}

Exemplo:

Texto observado:

Possibilidade em português:

Em espanhol:

Processo de interlíngua
TUDO

Tambem tudo mundo é acolhedor.

Também todo mundo é acolhedor.

También todo el mundo es acogedor.

Estratégia de comunicação 
Trata-se de uma interferência ortográfica da LE. Erro ortográfico cometido devido à surdez fonológica na inserção em um contexto de aprendizagem de PLE. O aluno confundiu a pronúncia do pronome indefinido TUDO com o adjetivo indefinido TODO por apresentarem semelhança fonológica. Além disso, com a inexistência de TUDO em espanhol, automaticamente, o aluno produz apenas TODO.

\section{(3) Troca de grafema}

Exemplo:

Texto observado:

Possibilidade em português:

Em espanhol:

Processo de interlíngua
ESSO

Eu gosto muito de esso.

Eu gosto muito disso.

Me gusta mucho eso.

Estratégia de comunicação

Trata-se de uma interferência ortográfica da LM e da LE. Em espanhol, ESO é pronome demonstrativo neutro, cujo equivalente em português é ISSO. Neste caso, o aluno acreditou que o equivalente de ESO em português é ESSO, pois alguns pronomes demonstrativos se escrevem com duplo "s". Ademais, a escrita correta em português desse pronome demonstrativo é com o grafema "i”.

\section{(4) Omissão de grafema}

Exemplo:

Texto observado:

Possibilidade em português:

Em espanhol:

Processo de interlíngua
$R O P A$

Por exemplo, os argentinos son muito preconceituosos sobre a roupa.

Por exemplo, os argentinos são muito preconceituosos sobre a roupa.

Por ejemplo, los argentinos tienen mucho prejuicio sobre la ropa.

Transferência linguística

Trata-se de uma interferência ortográfica da LM. O equivalente em português do substantivo ROPA, em espanhol, é ROUPA. O aluno omitiu o grafema "u" devido à semelhança com a grafia da LM. 


\section{(5) Acréscimo de grafema}

Exemplo:

Texto observado:

Possibilidade em português:

Em espanhol:

Processo de interlíngua
VANIDOSOS

Eles son muito vanidosos.

Eles são muito vaidosos.

Ellos son muy vanidosos.

Transferência linguística

Trata-se de uma interferência ortográfica da LM. O equivalente em português do adjetivo VANIDOSO, em espanhol, é VAIDOSO. O aluno adicionou o grafema "n" devido à semelhança com a grafia da LM.

\section{(6) Acréscimo de grafema}

Exemplo:

Texto observado:

Possibilidade em português:

Em espanhol:

Processo de interlíngua

\section{FALHAR}

Eles gostam de falhar sobre as festas.

Eles gostam de falar sobre as festas.

A ellos les gusta hablar sobre las fiestas.

Hipergeneralização de material linguístico de LE

Trata-se de uma interferência ortográfica da LE. O equivalente em português do verbo HABLAR, em espanhol, é FALAR. O aluno adicionou o grafema " $h$ " devido ao fato de que em português existem muitas palavras que se escrevem com esse grafema, por exemplo: trabalhar, falhar, etc.

\section{(7) Omissão de acento}

Exemplo:

Texto observado:

Possibilidade em português:

Em espanhol:

Processo de interlíngua
CONTRARIO

Eles têm muito respeto por a diversidade cultural ao contrario da gente na Argentina.

Eles têm muito respeito pela diversidade cultural ao contrário da gente na Argentina.

Ellos tienen mucho respeto por la diversidad cultural al contrario de a gente en Argentina.

Transferência linguística

Trata-se de uma interferência ortográfica da LM. O equivalente em português do substantivo CONTRARIO, em espanhol, é CONTRÁRIO. $\mathrm{O}$ aluno omitiu o acento agudo no grafema $\boldsymbol{a}$ devido à semelhança com a grafia da LM. 


\section{(8) Acréscimo de acento}

$\begin{array}{ll}\text { Exemplo: } & \text { BÔM } \\ \text { Texto observado: } & \text { Mais bôm a mia experiencia é ótima } . \\ \text { Possibilidade em português: } & \text { Mas bom, a minha experiência é ótima } . \\ \text { Em espanhol: } & \text { Pero bueno, mi experiencia es óptima. } \\ \text { Processo de interlíngua } & \text { Estratégia de comunicação }\end{array}$

Trata-se de uma interferência ortográfica da LE. O equivalente em português do adjetivo BUENO, em espanhol, é BOM. O aluno adicionou o acento circunflexo no grafema "o" devido ao fato de que em português, algumas palavras apresentam acentos circunflexos (acento que não existe em espanhol), talvez para marcar o fonema fechado da vogal "o", diferentemente da vogal aberta, que em geral está marcada graficamente com o acento agudo.

\section{(9) Palavras da língua materna com grafia da língua estrangeira}

Exemplo:

Texto observado:

Possibilidade em português:

Em espanhol:

Processo de interlíngua

\section{TENHE}

Nós temos llamas como a gente aqui tenhe cachorros.

Nós temos lhamas como a gente aqui tem cachorros.

Tenemos llamas como la gente aquí tiene perros.

Estratégia de comunicação

Trata-se de uma interferência da LM e a LE. Em espanhol, a conjugação do verbo "tener" na terceira pessoa do singular é TIENE. Em português, a conjugação do verbo "ter" na terceira pessoa do singular é TEM. O aluno fez uma aplicação de uma grafia comum em português (nh) na forma da palavra em espanhol "tiene": TIENHE, por assimilação da primeira pessoa do singular deste verbo em português: TENHO, fator que poderia marcar um nível mais avançado de aprendizagem de português.

Em geral, ao analisar as interferências linguísticas, verificou-se que a interlíngua dos alunos hispanofalantes de PLE está marcada pela instabilidade e sistematicidade. Assim, podem ser consideradas duas etapas de interlíngua nesses alunos segundo a classificação de Corder. De um lado, a pré-sistemática, pois muitos alunos hispanofalantes realizam hipóteses sobre a LE nas redações, evidenciando a recorrência da LM na escrita em português. De outro lado, a emergente, ao observar que esses 
alunos possuem conhecimentos das normas linguísticas da LE, no entanto, a maioria das vezes eles erram no uso dessas regras. Em consequência, conforme a interpretação de Durão sobre a interlíngua como continuum linguístico, a representação mental de PLE está sendo construída com base nos conhecimentos do espanhol. Isto pode representar a existência de "barreiras" que esses alunos devem superar para não fazer mais uso dos seus conhecimentos prévios relacionados à LM na escrita em português, mas também podem representar uma colaboração em tal processo, pois as semelhanças podem tanto confundir como promover a aprendizagem de línguas próximas. $\mathrm{O}$ diferencial será a conscientização do aluno em seu processo de aprendizagem da língua alvo. Neste sentido, surge a aplicação e análise do questionário, subseção a seguir.

\subsection{Análise do questionário}

Nesta subseção apresenta-se a análise do questionário aplicado aos alunos hispanofalantes o qual trata sobre o papel da LM na aprendizagem de PLE. Além de apresentar as análises estatísticas das respostas, mostram-se as justificativas mais recorrentes utilizadas pelos alunos.

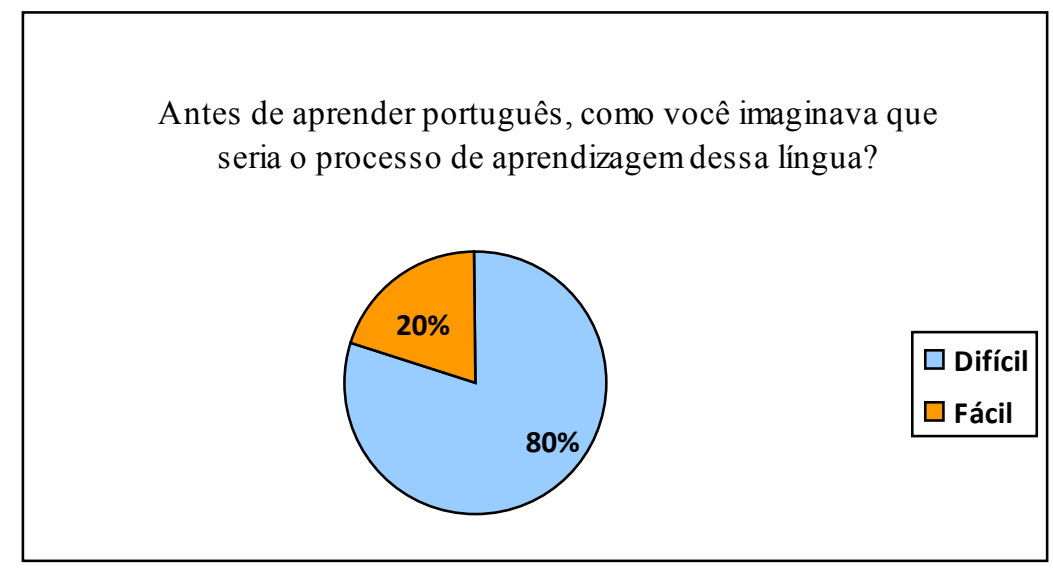

GRÁFICO 1: Pergunta 1

Para a resposta "difícil", a justificativa mais utilizada se baseia na existência de alguns aspectos linguísticos do português que torna sua aprendizagem complexa. No entanto, poucos alunos acreditam que 
o processo é fácil porque o espanhol e o português são línguas muito parecidas

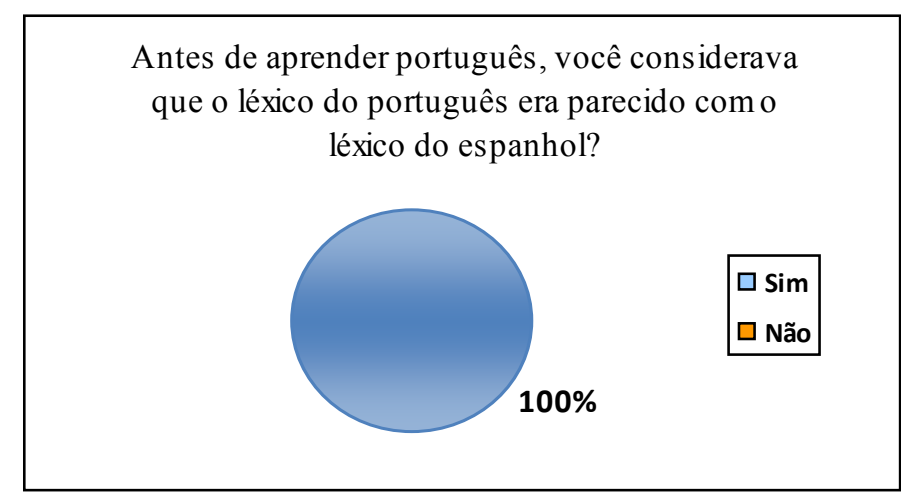

GRÁFICO 2: Pergunta 2

Todos os alunos responderam afirmativamente e a justificativa mais utilizada foi: as palavras são entendíveis e de fácil assimilação.

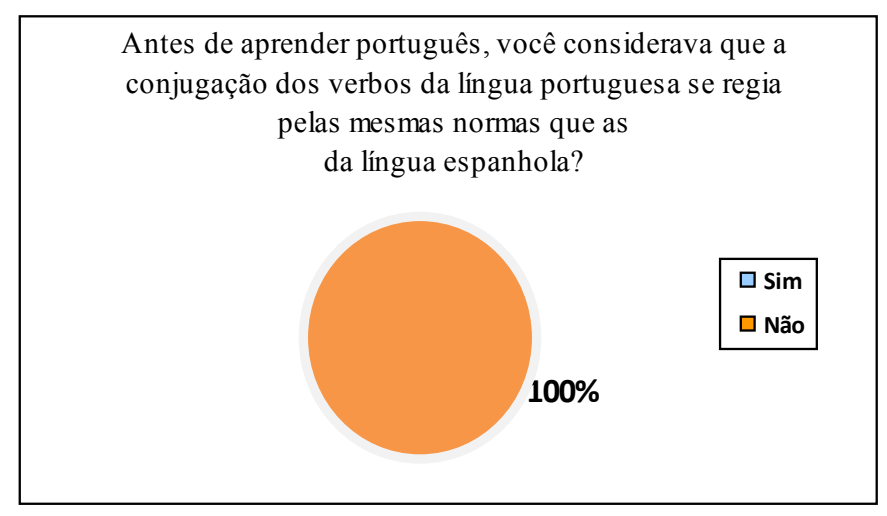

GRÁFICO 3: Pergunta 3

Todos os alunos responderam negativamente. Ajustificativa mais utilizada foi: existem terminações de conjugações que confundem aos hispanofalantes nos tempos verbais. 


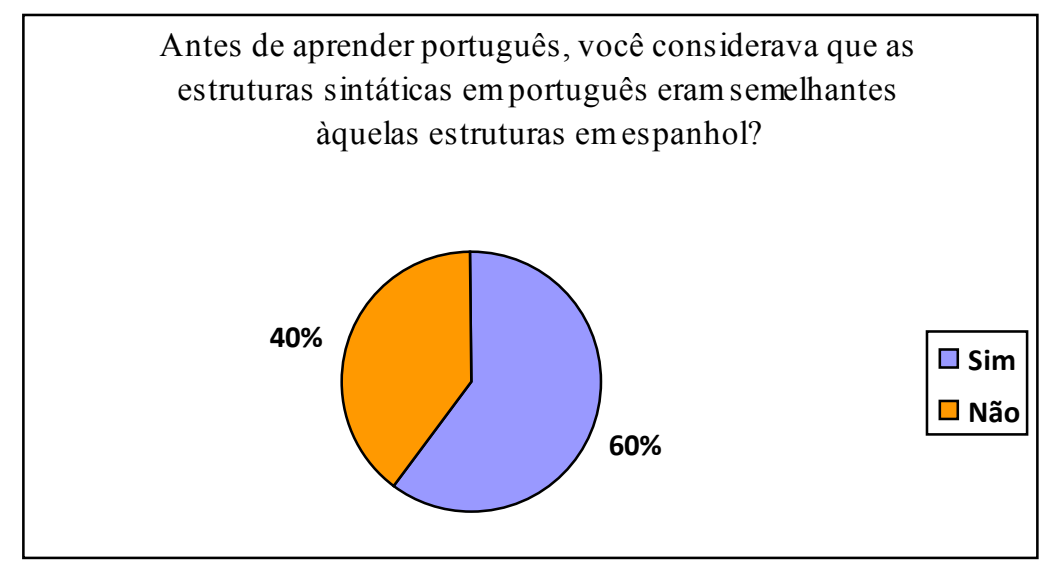

GRÁFICO 4: Pergunta 4

De um lado, para a resposta "sim", a justificativa mais utilizada foi: é fácil estabelecer uma oração em português seguindo o mesmo padrão de sujeito e predicado do espanhol. De outro lado, para a resposta "não", a justificativa mais utilizada foi: porque existem algumas estruturas sintáticas que têm ordens distintas do espanhol.

Antes de aprender português, você considerava que as ortografias dessas duas línguas eramidênticas?

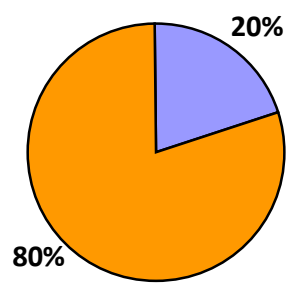

$\square \operatorname{Sim}$

$\square$ Não

GRÁFICO 5: Pergunta 5 
A maioria dos alunos respondeu "não" e a justificativa mais utilizada foi: o português possui regras muito diferentes e existem acentos que não existem em espanhol. Entretanto, poucos alunos responderam "sim", justificando que as duas línguas apresentam quase as mesmas letras porque elas provêm do latim.

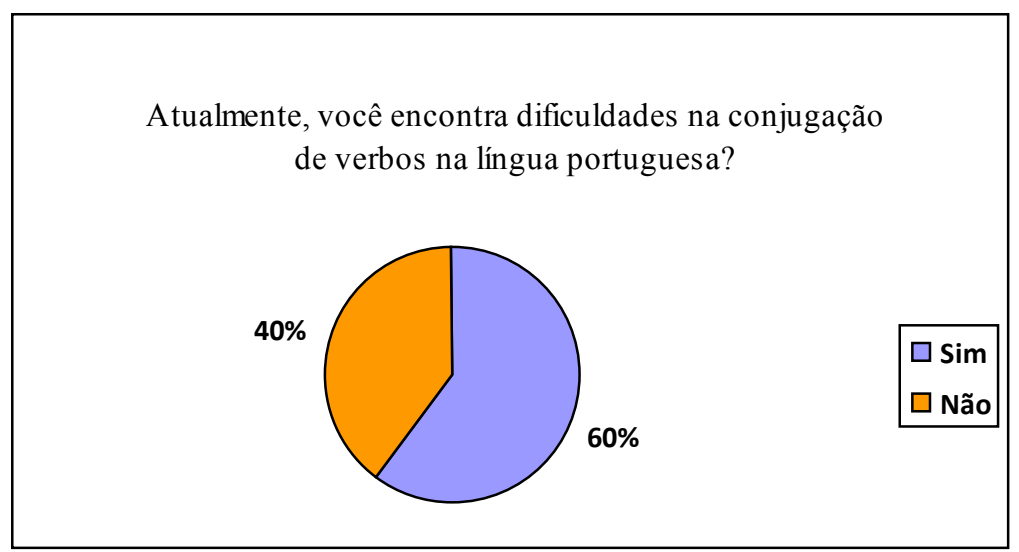

\section{GRÁFICO 6: Pergunta 6}

Para a resposta "sim", a justificativa mais utilizada foi: os tempos de conjugação como os tempos compostos são difíceis. Não obstante, para a resposta "não", a justificativa mais utilizada foi: a conjugação dos verbos regulares é fácil.

Atualmente, você encontra dificuldades na aprendizagem de estruturas sintáticas da língua portuguesa?

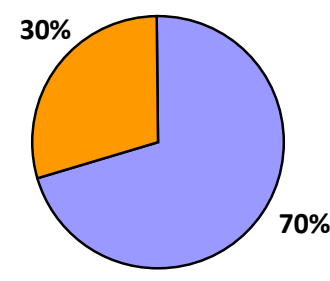


Observa-se que $70 \%$ dos alunos respondeu afirmativamente e a justificativa mais utilizada se baseia em que às vezes se realiza a construção errada das frases, pois ainda está latente a língua materna, porém 30\% dos alunos respondeu "não", argumentando que o português é muito parecido com o espanhol.

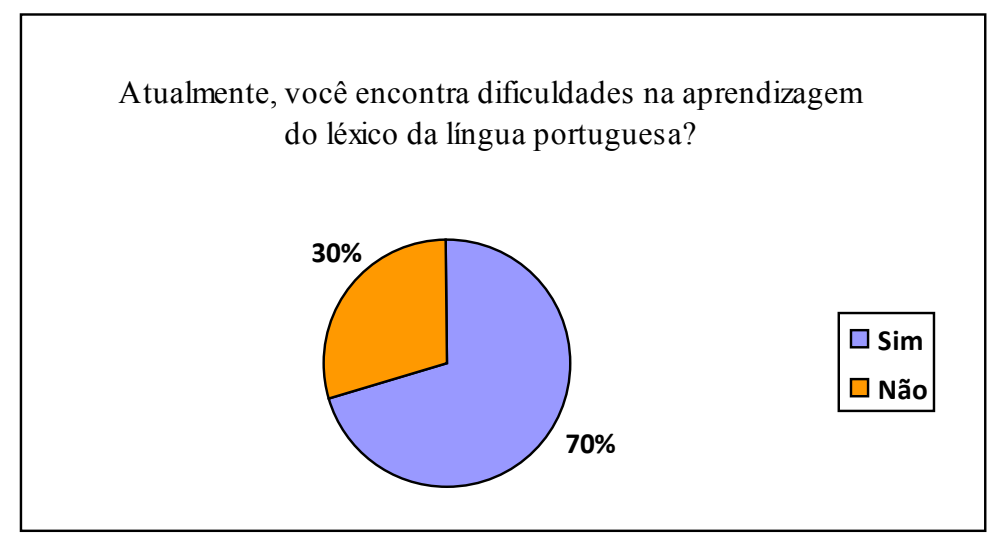

GRÁFICO 8: Pergunta 8

Do mesmo modo, $70 \%$ dos alunos respondeu "sim" justificando que embora muitas palavras sejam quase iguais ao espanhol, existem algumas mudanças que confundem. Além disso, 30\% dos alunos respondeu "não", mencionando que por muitas delas serem parecidas ao espanhol se aprende rápido.

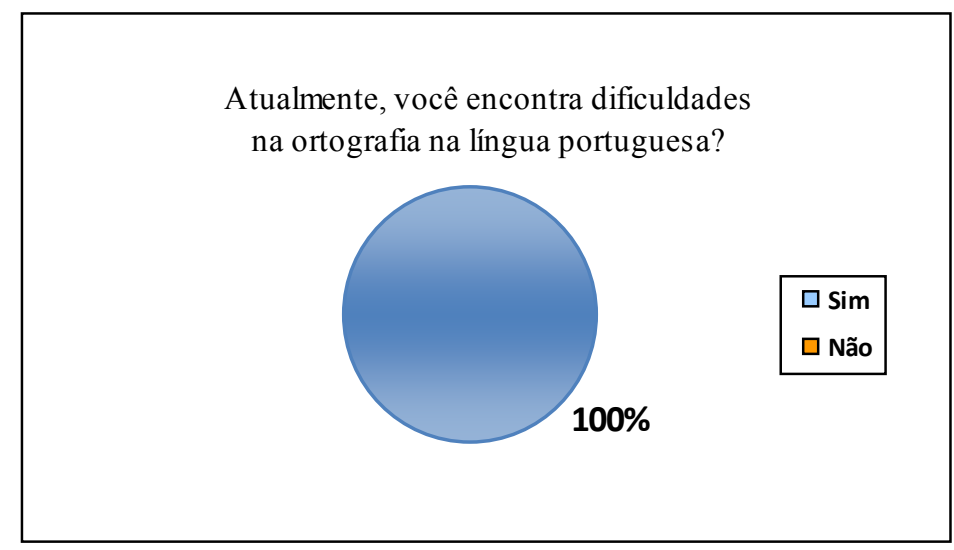

GRÁFICO 9: Pergunta 9 
Neste caso, $100 \%$ dos alunos respondeu "sim" e a justificativa mais utilizada foi: principalmente no uso dos acentos e mudanças nas grafias das palavras com igual som em espanhol.

Atualmente, você acha que a língua espanhola interfere no aprendizado da língua portuguesa?
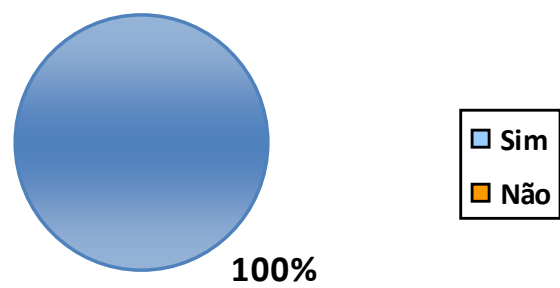

$100 \%$

GRÁFICO 10: Pergunta 10

Nesta pergunta, todos responderam "sim", argumentando que na hora de aprender português, se faz uso dos conhecimentos em espanhol.

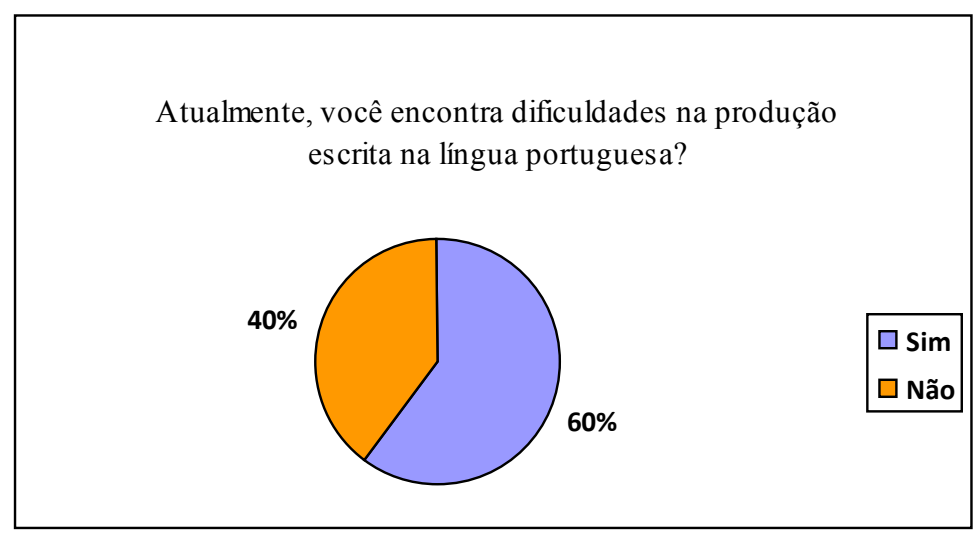

GRÁFICO 11: Pergunta 11 
Sobre a produção escrita, $60 \%$ dos alunos respondeu afirmativamente e a justificativa focaliza que sempre se recorre às normas do espanhol, as quais atrapalham suas produções linguísticas. Entretanto, $40 \%$ respondeu "não", argumentando que a produção escrita é parecida em espanhol, e não existe dificuldade nenhuma na hora de escrever.

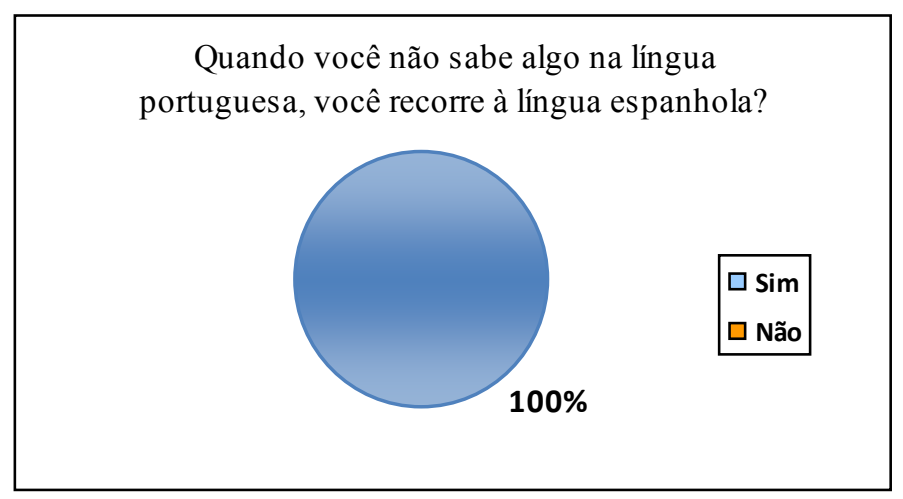

\section{GRÁFICO 12: Pergunta 12}

No referente a recorrer à língua materna, todos responderam "sim", justificando que a língua materna rege o pensamento e o inconsciente deles quando aprendem português na sala de aula.

Depois de ter analisado as respostas e as justificativas dos alunos em relação ao questionário sobre o papel da LM durante o processo de aprendizagem de PLE, concluiu-se que as dificuldades que surgem no processo de aprendizagem do português em alunos hispanofalantes estão relacionadas intrinsicamente àquelas semelhanças linguísticas no nível semântico, sintático e ortográfico entre essas duas línguas (espanhol e português), pois o uso das regras linguísticas da LM causou interferências linguísticas nas produções escritas desses alunos, como pode ser comprovado na análise apresentada neste estudo.

\section{Considerações finais}

O presente trabalho apresentou um enfoque sobre as interferências linguísticas no nível semântico, sintático e ortográfico em alunos hispanofalantes no nível intermediário de PLE em contexto de imersão. 
Observou-se que as interferências ortográficas são as mais recorrentes nas produções escritas daqueles alunos (75\%). Ao analisar especificamente os casos, percebeu-se que nas interferências semânticas se apresentam mais construtos linguísticos de Falsos Cognatos (67\%). Nas interferências sintáticas se apresentam mais construtos linguísticos de Omissão de contração (38\%); no nível ortográfico, identificaram-se mais casos linguísticos de Troca de grafema (56\%). Quanto à origem, verificou-se que a maioria das interferências linguísticas provêm da LM. Pôde-se concluir que o filtro cognitivo da LM configura um papel importante na aprendizagem de uma LE próxima à LM.

Em relação à análise dos processos de interlíngua definidos por Selinker, percebeu-se que a maioria das interferências linguísticas identificadas nos textos foram realizadas utilizando regras e subsistemas da LM. Contudo, poucas vezes os alunos realizaram mudanças nas regras da LE para poder se comunicar em português. Além disso, identificouse que raramente esse grupo de alunos generalizou regras gramaticais da LE em processo de aprendizagem no seu discurso, as quais foram inapropriadas em diversas frases ocasionando, assim, a criação de construtos linguísticos incorretos na LE.

Deste modo, segundo as definições de Corder, as análises informam que a interlíngua dos alunos hispanofalantes de PLE encontrase tanto na etapa pré-sistemática como na emergente, porque se realizam hipóteses sobre a LE, e, apesar de existir uma assimilação de regras da LE, os alunos não conseguem corrigir seus próprios erros e os cometem repetidamente. Este fato, pode promover a aprendizagem do aluno quando toma consciência de sua etapa como aprendiz e também promover o ensino ao professor que estimula o aluno para lidar com estratégias alternativas em seu processo de interlíngua.

Com relação ao conceito de Durão sobre a representação mental da interlíngua, pode-se observar que os alunos hispanofalantes internalizam os novos conhecimentos da LE, mas baseando-se no uso da LM. Isto pode resultar em passar por "dificuldades de aprendizagem" devido às semelhanças linguísticas entre a LM e a LE, ou seja, entre espanhol e português, línguas tipologicamente próximas, mas também devem ser vistas como promotoras do processo de ensino e aprendizagem, em contraposição com línguas muito diferentes. Ademais, pode-se considerar que o fato do aluno aprender PLE em um contexto de imersão 
pode ser favorável para atravessar as etapas de aprendizagem e superar a interlíngua de modo mais rápido e significativo.

A respeito das percepções de alunos hispanofalantes sobre a aprendizagem de PLE em contexto de imersão, verifica-se que a LM pode dificultar a aprendizagem do português em níveis mais avançados, provocando assim casos de interferências linguísticas nas redações daqueles alunos, este dado pode ser observado tanto nas análises linguísticas como na resposta 11, sobre recorrer a LM. Por outro lado, ao analisar as respostas do questionário, especificamente as perguntas 10 e 12, foi possível verificar que a proximidade tipológica parece ser um facilitador da aprendizagem, pois $100 \%$ dos alunos verbalizam que recorrem a sua LM, espanhol, ao utilizar a língua portuguesa, entretanto, justamente este fator de aproximação com a LM é que pode provocar a interlíngua.

À guisa de conclusão, é importante ressaltar que o professor de PLE deve tratar as interferências linguísticas durante o processo de ensino e aprendizagem, principalmente em níveis mais avançados e em contexto de imersão, entendendo que o aluno hispanofalante geralmente se encontra exposto a um conflito contínuo entre as regras e os hábitos adquiridos de português com a sua LM, espanhol, no caso de línguas próximas. Deste modo, com essa análise, pretendeu-se proporcionar um estado de conhecimento das interferências linguísticas na interlíngua em alunos hispanofalantes de PLE em contexto de imersão e sua descrição, para que os professores de PLE levem-nos em conta nas salas de aula e possam reduzir os desvios de aprendizagem nesses campos linguísticos e elaborar estratégias que tratem essas interferências.

\section{Referências}

ALMEIDA FILHO, J. C. P. Português para estrangeiros: interface com o espanhol. São Paulo: Pontes Editores, 2001.

ATIENZA, E. et al. Una tipología de interferencias catalán-castellano a partir de las producciones escritas de los estudiantes universitarios. In: CANTERO, F. et al. (Ed.). Didáctica de la lengua y la literatura para una sociedad plurilingüe del siglo XXI. Barcelona: Universidad de Barcelona, 1996. p. 577-582. 
BAETENS, H. Bilingualism: Basic Principles. Boston: College Hill Press, 1986. PMCid:PMC387218.

BARALO, M. Lingüística aplicada: aprendizaje y enseñanza del español/le. Interlingüistica, n. 14, p. 31-44, 2003.

BARALO, M. La adquisición del español como lengua extranjera. Madrid: Arco Libros. 1999.

BLAS ARROYO, J. La Interferencia Lingüistica en Valencia. (dirección: catalán-español). Castellón: Universitat Jaume I, 1993.

BYBEE, J. Frequency of Use and the Organization of Language. Oxford: Oxford University Press, 2006.

CORDER, S. P. The study of learners' language: error analysis. Introducing Applied Linguistic. Harmondswort: Penguin Books, 1973. p. 256-294.

DURÃO, A. B. A. B. La Interlengua. Madrid: Arco/Libros, 2007. PMCid:PMC3301216.

ELLIS, R. Understanding Second Language Acquisition. Oxford: Oxford UniversityPress, 1989.

FERNÁNDEZ, S. Interlengua y análisis de errores en el aprendizaje del español como lengua extranjera. Madrid: Edelsa, 1997.

INSTITUTO CERVANTES. El español, una lengua viva. Informe 2014. Madrid: Instituto Cervantes, 2014. Disponível em: $<$ http://eldiae.es/wpcontent/uploads/2014/07/El-espa\%C3\%B1ol-lengua-viva-2014.pdf $>$. Acesso em: 9 mai. 2015.

LADO, R. Linguistics across cultures. Ann Arbor: Michigan University Press, 1957.

LADO, R. Lingüistica Contrastiva: lenguas y culturas. Tradução de Joseph A. Fernandez. Madrid: Alcalá, 1973.

NEMSER, W. Approximative systems of foreign language learners. IRAL, v. 9, n. 2, p. 115-124, 1971. https://doi.org/10.1515/iral.1971.9.2.115.

ODLIN, T. Language transfer: cross-linguistic influence in language learning. Cambridge: Cambridge University Press, 1997. 
OVERBEKE, M. Mécanismes de l'interférence linguistique. Madrid: Fragua, 1976.

PAYRATÓ. La interferencia linguística. Cataluña: Curial Edicions Catalanes, 1985.

SANTOS GARGALLO, I. Lingüística Aplicada a la enseñanzaaprendizaje del español como lengua extranjera. In: LICERAS, J. La adquisición de Lenguas Extranjeras. Hacia un modelo de análisis de la interlengua. Madrid: Visor, 1999.

SANTOS GARGALlO, I. Análisis Contrastiva, Análisis de Errores e Interlengua en el marco de la Lingüistica Contrastiva. Madrid: Sintesis, 1993.

SELINKER. The Interlanguage. IRAL, v. 10, n. 3, p. 209-232, 1972.

SOUSA, D. Cómo aprende el cerebro. Thousand Oaks: Corwin Press, 2002.

TRAGER, G. L. The field of linguistics. Studies in Linguistics: Occasional Papers 1. Norman, Okla: Battenburg Press, 1949.

WATSON, J. Psychology as a Behaviorist Views. Psychological Review, Washington, v. 2. p. 158-177, 1913. https://doi.org/10.1037/h0074428.

WEINREICH, U. Languages in contact. La Haya: Mouton, 1953.

ZOPPI FONTANA, M.; DINIZ, L. R. A. Declinando a Língua pelas Injunções do Mercado: Institucionalização do Português Língua Estrangeira (PLE). Estudos Linguísticos, São Paulo, v. 27, p. 89-119, 2008. 